\title{
Economic Forces and their Effect on Civic Participation Throughout United States History
}

\author{
Anant Gupta ${ }^{1}$ and James Coe Jr. ${ }^{1}$ \\ ${ }^{1}$ Newark Academy, Livingston, NJ, USA
}

\section{ABSTRACT}

Throughout U.S. history, Economic events and legislation have led to civic activism in the form of protesting and political disruption and have had long term social effects that are seen in the present. The economic history of the United States has been one of unprecedented success and unparalleled growth. At the founding of our country, Alexander Hamilton envisioned a financial structure that would prioritize the well-being of the populace and ensure the stability of the United States economy. However, he could have never envisioned the effect that economic events and fiscal legislation would have on the common people in terms of civic activism. The economy is so interwoven into the fabric of society that any change in it has the potential to create a social revolution, and it has. The nature of economics and its pervasiveness throughout society makes it a potent catalyzer for change. In this paper, two major events were explored. First, the causes of The Panic of 1873, the United States' transition to the Gold Standard, and their implications. Additionally, the social effect which manifested itself through the Free Silver Movement and William Jennings Bryan is dissected. Second, the 2008 Financial Crisis is explained, including the systematic failures that allowed it to occur, and the creation of the Occupy Wall Street Movement. Lastly, an intriguing take on 21 st-century civic activism is explored, with Social media and digital presence illustrated as champions for modern social cum political change

\section{Introduction}

The economic history of the United States has been one of unprecedented success and unparalleled growth. At the very founding of our country, Alexander Hamilton envisioned a financial structure that would prioritize the well-being of the populace and ensure the stability of the United States economy. However, he could have never envisioned the effect that economic events and fiscal legislation would have on the common people in terms of civic activism. The economy is so interwoven into the fabric of society that any change in it has the potential to create a social revolution, and it has. While other movements such as Civil or Women's Rights have had a lasting impact, the nature of economics and its pervasiveness throughout a society makes it a much more potent catalyzer for change. Throughout U.S. history, Economic events and legislation have led to civic activism in the form of protesting and political disruption and have had long term social effects that are seen in the present.

A clear example of where economic legislation influenced civic involvement can be seen with the Coinage Act of 1873 and the Free Silver Movement. During the post-Civil War era (the mid-1860s to early 1870s), the inflation rate of the United States Economy was hovering between $-6.92 \%$ and $-5.0 \%$ - the fourth-largest negative inflation rate in the country's history. While this initially may seem beneficial, this condition hurts the population and only occurs after a recession and is symptomatic of a weak economy that has a limited flow of capital and exchange goods and services. Wanting to prevent further negative inflation (deflation), President at the time Rutherford B. Hayes decided that he would force the Federal Reserve to remove the silver coin as legal tender. Hence, he signed into law The Coinage Act of 1873. Until this point, the US had been on a dual-coinage system (known as Bimetallism) with 
all currency being backed by gold and silver. President Hayes' justification for removing the silver coin from circulation had various facets. The first was that the common vehicle for transactions were "greenbacks," federally established legal tender created during the Civil War, and not silver, which was seen as more valuable and hoarded. The second, supported by Gresham's Law, was that gold was not being used for expenditures as it had a higher exchange rate compared to silver. Additionally, gold was more liquid as a commodity and preferred for savings. The economic effect that Hayes wanted to attain can be illustrated as follows:

1. Consider the scenario that the US economy is worth $\$ 100$ and its value stems from $1 \mathrm{oz}$ of silver and $1 \mathrm{oz}$ of gold.

2. New legislation is passed that removes the ounce of silver from the system,

3. The value of the economy is now solely tied to the $1 \mathrm{oz}$ of gold, depreciating the currency and creating inflation.

4. Now, an incentive is created for businesses to produce goods as they feel confident that they can make a profit off of them, promoting a healthy economic environment.

While this seemed like the logical economic principle to apply, for many Americans, this was an egregious violation of their economic freedom. The mining community had a vested interest in maintaining silver as the predominant currency as it employed many Americas. Additionally, relying solely on gold would lower the stability of the system as the commodity would be more susceptible to external forces (gold robberies, mines flooding, etc.). This perception gave the Coinage Act the name, "The Crime of 1873." With a deflated economy hurting those in debt, as it makes the real value of dollars needed to pay off the debt higher, hence farmers and laborers opposed the gold arrangement. Simultaneously, an inflated economy benefits creditors and those lending as they get more back when the debt is paid and thus, banks and businessmen supported removing silver from circulation.

This tension between these opposing views led to the formation of the Free Silver Movement, with fiery orator and one of the greatest politicians of all time, William Jennings Bryan, at its helm. William Jennings Bryan was a talented lawyer from Illinois who fed off of public disdain for the passing of the Silver Coinage Act to become a formidable political agent. The passing of the Coinage Act galvanized citizens into taking action, which presented itself in the form of political power supporting Bryan. Over the next twenty years, the Free Silver Movement would grow and eventually dominate the political field. The culmination of this effort was seen during the 1896 presidential campaign, where William Jennings Bryan presented his "Cross of Gold" speech at the Democratic National Convention as a bid for the nomination. His speech touched upon the struggles of the common American, and how he stood on the platform because he represented the voice of the country. This was his way of being a part of the civic process. It was a miracle that he had gotten that far, but the grassroots support he had garnered presented itself as a mass summation of political will. He finished his speech in an iconic manner:

"The people will not be oppressed any longer and have the right to a system of money that benefits them. Having behind us... all the toiling masses, we shall answer their demands for a gold standard by saying to them...You shall not crucify mankind upon a cross of gold."

For citizens at the time, civic activism was best expressed via political disruption. This radical historical shift in the political sphere required continuous civic action over a twenty-year period, which eventually turned public opinion positively towards the Democrats, affecting future voting patterns. Thus, proving how legislation that affects everyone is an effective catalyzer for civic activism.

Moving 112 years into the future, the United States witnessed the largest financial crisis to occur since the Great Depression, the 2007-2008 Financial Crisis. The effects of the economic crash were felt through every aspect of American life, with businesses shutting down, and 2.6 million Americans losing their jobs. The main cause of this economic catastrophe, ironically similar to that of the Panic of 1893, was the housing and mortgage market. At the 
time, mortgages were sold as investments in a real-estate bubble riddled with over-speculation in the belief that property prices would continue to increase. As with any over-speculated asset, the bubble had to burst at some point. The reason the bubble got so big, however, was the availability of cheap credit and the increasing gap between people's debts and income. To further exacerbate the situation, Wall Street Investment bank, Lehman Brothers, declared bankruptcy due to its loss of its $\$ 85$ billion portfolio consisting of mortgage-backed securities. Lehman Brothers was one of the oldest, richest, and supposedly most stable banks in the world, so much so that many have stated, "It was too big to fail." However, this stature was misleading as the assets that they had were inflated and not valued accurately. Thus, despite having an estimated $\$ 638$ billion in assets, it was unable to avoid bankruptcy and took an estimated $\$ 613$ billion of debt with its collapse and causing billions of losses in the world market. However, investigations traced the cause of the crisis back to an oversight on the parts of big banks and government, and a lack of transparency for investors.

In the years after the crisis, public sentiment about Wall Street declined and in the place of trust grew anger. Thus, in 2011, the "Occupy Wall Street" movement was born. On September 7, 2011, in Zuccotti Park, New York City, hundreds of protesters congregated and demanded a change to the current system, one that left behind the majority of the country and pandered to the few. The Occupy Wall Street movement was a collection of displeased citizens: minimum-wage workers, small business owners, and laborers who had been abandoned by the economy and took the brunt of the economic collapse. The movement had a broad and ambitious set of goals, but at the center of it all was the hopeful prevention of a catastrophe like 2008 from ever happening again and to hold those responsible (mainly Wall Street Executives) accountable. Over the movement's lifetime, this goal expanded and new objectives as they aimed to address public issues such as income disparity, increase regulations on big business, and even increasing the minimum wage, free and fair elections, and environmental protection. What makes the Occupy movement so integral to civic activism is how it brought together people from all parts of life to advocate for a cause that affected everyone. It was an organic organization, with no leader or figurehead, but a collective of concerned citizens that took advantage of the right to assemble. Armed with the slogan, "We are the $99 \%$," Occupy brought attention to the increasing economic disparity in America and how when united, the common populace can take back power from the few. This message cum ideology has since become mainstream, with Senator Bernie Sanders echoing its sentiment and has been seen as a champion of the cause. The movement gained an important victory in 2011 with the passing of the Dodd-Frank Act, specifically the Volcker Rule, Title VI of the Dodd-Frank Act, which placed restrictions on the ability of Investment banks to pursue speculative investments and trade in Derivatives. For context, the Dodd-Frank Act (abrv.) was a large piece of economic legislation that aimed to curtail the chance for instability in large investment banks through regulations and the creation of oversight committees such as the Consumer Financial Protection Bureau (CFPB). Within the Volcker Rule's 900 pages of preamble and 71 pages of actual law, the Occupy movement was cited an astounding 284 times. Overall, The Occupy Wall Street Movement has shown that economic hardships elicit a strong civic response and help create change in our society.

And yet, in an era where technology has facilitated people's ability to exercise their civic will, it is worth looking further into Occupy Wall Street as a means of seeing what civic activism truly looks like in the 21st century. Nowadays, in place of writing to the editor of a local newspaper, people will express their views on social media. The potential for ideas and movements to reach new people is frankly unlimited considering the scope of the Internet. For example, during the timeframe when the Dodd-Frank Act was being voted on in the Senate, people went to social media platforms such as Twitter to express both support and concern about the passing of the act. Looking at the tweets posted, one sees a variety of views from a variety of people. The spectrum of stances seen ranges from mildly against to overwhelmingly positive. Some users were a part of an organization and some were just individuals sharing opinions. For example, Tankint Wiggy, a small unassuming musician in San Bernardino, CA shared his two cents about the movement post-Dodd-Frank, “...Finish what Dodd-Frank started/end too big to fail/ \#occupy \#goals." Or, take Nick Sorrentino, co-founder of a small news company, who had some reservations about Dodd-Frank tweeting, “...Dodd-Frank has created a 2 tiered economy - To [sic] Big to Fail, and the rest of us...\#Tcot \#occupy." What is important to see here is how even a small, seemingly insignificant act of expression from normal individuals is an 
involvement in the civic process. It may be different than how it used to be in the past, but the ability to influence the future of the country makes it valuable, nonetheless. New methods of participation have ensured that now, more than ever, civic participation is accessible to the citizenry and continues to grow for the good of the country.

As one looks back on nearly 250 years of economic history and events, the effect that these occurrences have had on society and people's civic activism is blazingly apparent. Through economic legislation that affected every citizen, people have combined their civic power and combined into new political movements that would change voting patterns and affect new laws to come. Economic Recessions had an even bigger part in motivating citizens to use their civic influence, by creating hard times that made people angry, creating protests and social movements in their wake that would forever change the political agenda and social discussion. Essentially, economic events and legislation have forced citizens to use the rights given to them by the Constitution, and thus, have contributed to the creation of a stronger democracy.

\section{Bibliography}

“About.” About Us | OccupyWallSt.org. Accessed May 18, 2020. http://occupywallst.org/about/.

Alexavm. "The Occupy Wall Street Movement.” NYCROPOLIS, May 10, 2018. https://eportfolios.macaulay.cuny.edu/vellon18/economic-inequality/alexavm/the-occupy-wall-street-movement/.

"America at the Turn of the Century: A Look at the Historical Context : Articles and Essays : The Life of a City: Early Films of New York, 1898-1906 : Digital Collections : Library of Congress." The Library of Congress, 2015. https://www.loc.gov/collections/early-films-of-new-york-1898-to-1906/articles-and-essays/america-at-theturn-of-the-century-a-look-at-the-historical-context/

Bryan, William Jennings. "Bryan's 'Cross of Gold' Speech: Mesmerizing the Masses.” History Matters - The U.S. Survey Course on the Web. Accessed February 11, 2020. http://historymatters.gmu.edu/d/5354/

Chappelow, Jim. “Gresham's Law Definition.” Investopedia, Investopedia, 29 Jan. 2020, www.investopedia.com/terms/g/greshams-law.asp.

DePillis, Lydia. "The Volcker Rule Cites the Occupy Movement 284 Times.” The Washington Post. WP Company, December 11, 2013. https://www.washingtonpost.com/news/wonk/wp/2013/12/11/the-volcker-rule-cites-the-occupy-movement-284-times/?arc404=true.

Dr. Pradeep Kumar, "Understanding Negative Inflation and its Effect on the Economy," interview by Anant K. Gupta, May 14, 2020

Dr. Pradeep Kumar, “The 2008 Crisis: Causes and Effects,” interview by Anant K. Gupta, May 17, 2020

"Inflation Rate between 1873-2020: Inflation Calculator." \$1 in $1873 \rightarrow 2020$ | Inflation Calculator. Accessed May 14, 2020. https://www.officialdata.org/us/inflation/1873?amount=1.

Kenton, Will. "Dodd-Frank Wall Street Reform and Consumer Protection Act." Investopedia. Investopedia, February 5, 2020. https://www.investopedia.com/terms/d/dodd-frank-financial-regulatory-reform-bill.asp.

Kemmerer, Edwin Walter. Gold and the Gold Standard: the Story of Gold Money - Past, Present and Future. Whitefish, MT: Literary Licensing, 2013. https://books.google.com 
/books?hl=en\&lr=\&id=_aDIEAre3GMC\&oi=fnd\&pg=PR5\&dq=Gold+Standard\&ots=MOXRsO2QtN\&sig=Q2Cu3 ZkF5elQzTgOpezC00kc9vY\#v=onepage\&q\&f=false

Landesman, Tucker, Twitter Post, December 14, 2013, 5:13 a.m. https://twitter.com/yosoytucker/status/411801127068241920

Levitin, Michael. "The Triumph of Occupy Wall Street." The Atlantic. Atlantic Media Company, June 11, 2015. https:/www.theatlantic.com/politics/archive/2015/06/the-triumph-of-occupy-wall-street/395408/.

McNamara, Robert. "What Was Coxey's Army?” ThoughtCo. ThoughtCo, April 8, 2019.

https://www.thoughtco.com/coxeys-army-march-of-unemployed-workers-1773910.

Noyes, Alexander D. "The Banks and the Panic of 1893." Political Science Quarterly 9, no. 1 (1894): 12-30. Accessed May 5, 2020. doi:10.2307/2139901.

Rauchway, Eric. “The 2008 Crash: What Happened to All That Money?” History.com. A\&E Television Networks, September 14, 2018. https://www.history.com/news/2008-financial-crisis-causes.

Singh, Manoj. “The 2007-08 Financial Crisis in Review.” Investopedia. Investopedia, January 29, 2020. https://www.investopedia.com/articles/economics/09/financial-crisis-review.asp

Sorrentino, Nick, Twitter Post, December 26, 2021, 10:19 p.m.

https://witter.com/LibertyandEcon/status/284136304143368192

The Editors of Encyclopaedia Britannica. "Bimetallism.” Encyclopædia Britannica. Encyclopædia Britannica, inc., April 6, 2018. https://www.britannica.com/topic/bimetallism The Editors of Encyclopaedia Britannica. "William Jennings Bryan.” Encyclopædia Britannica. Encyclopædia Britannica, inc., March 15, 2020. https://www.britannica.com/biography/William-Jennings-Bryan.

“The Panic of 1893." The Panic of 1893 | Florence Kelley in Chicago 1891-1899. Accessed May 13, 2020. https://florencekelley.northwestern.edu/historical/panic/ .

Uchitelle, Louis. "U.S. Lost 2.6 Million Jobs in 2008.” The New York Times. The New York Times, January 9, 2009. https://www.nytimes.com/2009/01/09/business/worldbusiness/09iht-jobs.4.19232394.html.

U.S. Congress, House, Dodd-Frank Wall Street Reform and Consumer Protection Act (Dodd-Frank ACT) Act of 2001, HR 4173, 111th Cong., 2nd sess., introduced in House July 15, 2010. Accessed May 17,2020 .https://www.govinfo.gov/content/pkg/BILLS-111hr4173enr/pdf/BILLS-111hr4173enr.pdf

"U.S. Mint History: The "Crime of 1873."' United States Mint. Accessed May 16, 2020. https://www.usmint.gov/news/inside-the-mint/mint-history-crime-of-1873.

Wiggins, Rosalind Z., Thomas Piontek, and Andrew Metrick, The Lehman Brothers Bankruptcy A: Overview, Yale Program on Financial Stability Case Study 2014-3A-V1, October 2014. Accessed May 13, 2020 http://som.yale.edu/sites/default/files/files/001-2014-3A-V1-LehmanBrothers-A-REVA.pdf .

Wiggy, Tanjint, Twitter Post, November 29, 2011, 12:46 p.m. https://twitter.com/Tanjint/status/141573665593638914 